\title{
Liberté, Liberté Chérie
}

\author{
Bernard Perbal • Annick Perbal
}

Received: 10 February 2015 / Accepted: 10 February 2015 / Published online: 1 March 2015

(C) The International CCN Society 2015

\begin{abstract}
As part of the Journal of Cell communication and Signaling publishing staff, we are very much attached to the freedom of expression given to our authors. This has been exemplified in our willingness to stimulate commentaries and open debates through the Bits and Bytes series published in JCCS.

Without willing to take part in the debate regarding the nature of the drawings published in Charlie Hebdo, we recognize the worldwide response to the recent murdering of journalists as strong support of freedom of the press, however, we also felt that attempts to silence other forms of expression, which are numerous these days, should be reminded and fought against.

In this editorial we pay homage to the victims of recent tragic events in Paris and to all who fight every day for freedom of expression.
\end{abstract}

Keywords Freedom of expression · Liberty · Journalism · Intolerance

At the dawn of 2015, we had originally planned to present to you the details of the new features that will be introduced this year, both in the Journal of Cell Communication and Signaling $^{1}$ and in the organization of the International Workshop on the CCN Family of Genes ${ }^{2}$ that will be held in Nice, November 3-8, 2015.

\footnotetext{
${ }^{1}$ for updates see http://springer.com/12079

${ }^{2}$ for meeting updates see http://ccnsociety.com
}

"This editorial is dedicated to the memory of the victims of recent tragic events in Paris and to all those who fight everyday for freedom of expression."

freedom, beloved freedom, from the sixth verse of La Marseillaise, composed by Rouget de Lisle in 1792 and which became the national anthem of France on July 14th 1795

B. Perbal: Editor in Chief, JCCS, President of the ICCNS

A. Perbal: Administrative Secretary of JCCS, member of the ICCNS Executive Board

B. Perbal $(\varangle) \cdot$ A. Perbal

International CCN Society, Nice, France

e-mail: bperbal@gmail.com
As part of a scientific community attached to and involved in improving the wellness of humanity, we were profoundly affected by the dramatic events that occured in Paris at the beginning of the year.

As the shootings constitue a frontal attack to freedom of expression in all its forms, we felt that we could not remain silent and would like to briefly express our deep concerns about manifestations of intolerance that are too frequent.

Many articles and comments have been published about the Paris events and the impact that they might have on our daily life.

It is neither our intention, nor the place, to attempt making a political analysis.

We leave that to all the state representatives ${ }^{3}$ who gathered for $15 \mathrm{~min}$ and paused for a prestigious photograph in an almost empty street opening the way of a Charlie's Republican rally whose marching participants were at quite a distance down the road !. ${ }^{4}$

Those who might want to have a different view on the significance of this political gathering should consult some of the articles that commented on the sincerity of the representatives of the governments depicted as among the most intolerant against freedom of the press.

Reporters without Borders ${ }^{5}$ was « appalled by the presence of leaders from countries where journalists and bloggers are systematically persecuted such as Egypt, Russia, Turkey, and the United Arab Emirates »" .

\footnotetext{
$\overline{3}$ http://www.rtbf.be/info/monde/detail des-dizaines-de-chefs-d-etatpresents-a-la-marche-republicaine? $\mathrm{id}=\mathbf{8 7 5 3 9 7 6}$; http://timesofindia. indiatimes.com/world/europe/List-of-leaders-who-attended-Paris-rally/ articleshow/45843350.cms

${ }^{4}$ http://www.independent.co.uk/news/world/europe/paris-march-tvwide-shots-reveal-a-different-perspective-on-world-leaders-at-largestdemonstration-in-frances-history-9972895.html; http://www. fromthetrenchesworldreport.com/paris-march-tv-wide-shots-a-differentperspective-on-world-leaders-at-demonstration-in-frances-history/ 118711

${ }^{5} \mathrm{http} / / /$ rsforg - Reporter Without Borders is a nonprofit organisation for freedom to be informed

${ }^{6} \mathrm{http}$ ://en.rsf.org/rwb-condemns-presence-of-predators-11-012015,47472.html
} 
Others ${ }^{7}$ also questioned the presence in the march of Ahmet Davutoglu, ${ }^{8}$ and Macky Sall ${ }^{9}$ given that a few days after the Paris march, Recep Tayyip Erdogan ${ }^{10}$ considered that the « provocative publications about muslims » by Charlie Hebdo « equates to wreaking terror by intervening in the freedom space of others » ${ }^{11}$

Also, at the same time, the Senegalese government decided that "It is forbidden to distribute and disseminate, by any means, today's editions of the French magazine 'Charlie Hebdo' and the French newspaper 'Liberation' throughout the national territory," 12

How to understand, in that context, that François Hollande asked Israel 's Prime Minister Benjamin Netanyahu not to attend the march $!^{13}$.

Although we do not deny that terrorism threat and racism have been growing at a fast pace over the past few years, we believe that the killings at Charlie Hebdo were not, as much as politicians claimed, part of a terrorist plot against France.

Past years have been rich in examples, all over the world, showing the ability of politics to take advantage of the situation and sometimes manipulate facts and people to create a state of terror when their popularity or credibility dropped. Lies that were propagated about Iraq are one amongst striking examples. ${ }^{14}$

We and many others, believe that the shooting at Charlie Hebdo was inspired by the humiliation that two integrist ${ }^{15}$ muslims had felt, like many others for several years, after the publication of drawings depicting their prophete.

\footnotetext{
${ }^{7}$ http://www.marianne.net/elie-pense/11-janvier-les-revirements-ceuxqui-sont-venus-1421516800.html

8 the Prime Minister of Turkey,

${ }^{9}$ the President of Senegal

${ }^{10}$ the President of Turkey,

${ }^{11} \mathrm{http}$ //news.yahoo.com/erdogan-lashes-provocative-charlie-hebdo141831978.html; ylt=A0LEV0kHCtZUV4gA8WBXNyoA; ylu= X3oDMTByMG04Z2o2BHN1YwNzcgRwb3MDMQRjb2x vA2JmMQR2dGlkAw-

$12 \mathrm{http}: / /$ news.yahoo.com/senegal-bans-charlie-hebdo-liberation-daily194623568.html; ylt=AwrBEiFuENZU0kgAeSvQtDMD

${ }^{13} \mathrm{http}: / /$ www.blacklistednews.com/Hollande_Furious_After Netanyahu Participates In Paris March\%2C Disobeying French President $\% 27$ s_Request $/ \overline{40786 / 0 / 38 / 38 / Y / M} \cdot \overline{M t m l}$; http://www. independent.co.uk/news/world/europe/paris-march-president-hollandeasked-israels-netanyahu-not-to-attend-paris-march-9971995.html

${ }^{14} \mathrm{http}$ ://www.globalresearch.ca/iraq-935-lies-a-tyrant-with-weapons-ofmass-destruction/5366991

${ }^{15}$ Integrism, (from the french word "integrisme") originally defined as an opposition to any development and evolution within a religious movement (cf Larousse encyclopedia), is also widely used in the modern days, to qualify a political uncompromising conservatism.

The Integrist political party created in Spain by Candido Nocedal in 1872 , was the party of uncompromising catholics who wanted that governments of any kinds, have to be under the authority of the church.

Nowadays, religious and political integrism is the matter of passionate debates (see for example Feminism, laicity, same fight against integrisms by Michèle Vianès http:/www.regardsdefemmes.com/ Documents/Interventions2010/Intervention_LONDRES_one_law_for_ all.pdf)

The resurgence of integrism is strong among intolerant muslim populations who are involved in terrorism.
}

The cartoonists had been threatened of death since 2006 .

Unfortunately, these violent acts found supporters and resulted in the ignition of other racist acts in several parts of the world soon after the Paris shootings.

As a consequence, fear developed and decisions were taken to avoid more damage.

For example, the projection of the movie « the apostle » 16 has been banned in France, for fear of reprisals.

For similar reasons the theater play entitled 《Lapidée ${ }^{17}$ has been stopped, as a consequence of « strongly suggested » autocensorship according to observers.$^{18}$

In the same vein, the Charlie Hebdo float has been canceled from the German Köln festival in which it was supposed to be included. ${ }^{19}$ The Charlie Hebdo exhibit originally organized by the Hergé museum and the projection of the movie Timbuktu have also been cancelled.. ${ }^{20}$

Of course we can imagine the fear that the population faced with terrorists threats, and we can appreciate how « the art of silence is taught by life's many ills $»^{21}$.

But, are these really appropriate decisions or small bandaids applied to the wound?

Although one can understand that terrorist plots must be forestalled by preventing them, some of the decisions that were taken in response to the cartoonist murdering appeared, in the eyes of some analysts, as the incapacity of governments to act efficiently against integrism intolerance.

Measures that have been taken after the Paris shooting sometimes remind us of the scene in the Dumbo Disney cartoon, where the firemen attempt to extinguish the fire with small buckets of water and pipets !

A recent poll run by the Pew Research Center ${ }^{22}$ indicated that further to the attack on the Charlie Hebdo magazine's staff, $76 \%$ of Americans who were contacted heard about the events, $60 \%$ of who said that based on freedom of speech in the press, it was okay to publish cartoons depicting the Prophet Muhammad, whereas $28 \%$-that is three in ten-, considered that the cartonists had gone too far $^{23}$

Even though we can understand that people may be shocked by acts or words that they consider irrespectful to their Presidents, Queens and Kings, or Gods, nothing, nothing

\footnotetext{
${ }^{16}$ the movie tells the story an aspiring Imam Akim, who decides to turn to Catholicism after the sister of a priest is murdered by a neighbor.

${ }^{17}$ « Stoned » play written by a minster of Lausanne. http://www.tdg.ch/ news/standard/censure-piece-drame-charlie-hebdo/story/21708812

18 http://blogs.mediapart.fr/blog/stephanelavignotteorg/140115/lacensure-douce-est-en-route-la-preuve-par-lapidee-piece-reportee-paris

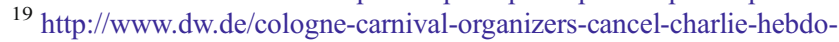
float/a-18222673

${ }^{20} \mathrm{http}$ ///abidjan911.com/belgique-le-film-timbuktu-ne-sera-pas-projete/ \#. The movie relates the story of a family from Mali in contact to religious extremists

${ }^{21}$ Seneca the younger. Thyestes, act II, scene 1

$22 \mathrm{http}: / /$ www.pewresearchcenter.org

${ }^{23} \mathrm{http}$ ://www.journalism.org/2015/01/28/after-charlie-hebdo-balancingpress-freedom-and-respect-for-religion/
} 
at all can justify murdering those who do not share one's opinions.

Such acts cannot be excused.

The dramatic shootings have focused the attention of people from France, and from many other countries, on the problem of « press freedom ».

Indeed, these events were another example of the worldwide explosion of integrism and intolerance.

From the European crusades that took place in the Middle and Late Middle Ages up to the ethnic cleansing that occured in the past few years in Africa, Middle East, Asia, Eastern Europe, History is full of intolerance, sectarianism and integrism, examples which translate into large scale murdering and abuse.

Freedom of the press is essential to humanity, but it often requires fighting to be maintained.

As members of the JCCS publishing crew, we are very sensitive to these aspects.

There are many examples from all over the world, of press censorship and reports of journalists being mistreated.

« Freedom of the press » seems to be an idiom with quite different meanings !

More than 200 journalists are in prison worldwide, for the third consecutive year ${ }^{24}$, with China being the worst offend$\mathrm{er}^{25}$ as reported by the Committee to Protect Journalists $(\mathrm{CPJ})^{26}$ who also reported that 1116 journalists had been killed since 1992, with already 13 in 2015, at the time this editorial is being written.

The World press freedom index for $2014^{27}$ that was published by Reporters Without Borders, provides an index about freedom of information in the world.

Finland ranks first, Germany 10th, UK 33rd, and USA 46th.

At the bottom of the list, China ranks 175th after Iran 173rd, and North Korea ranks 179th at the penultimate position just before Eritrea.

France traditionally considered as a good defender of press freedom before 2013, only ranked 39th in 2014.

Examples of information control in affairs involving leading politicians accused of « freedom violation » by RSF (see the 2014 world press report) were deleterious.

As a matter of fact, many people in France now feel that freedom of expression is vanishing because of integrism and sectarianism exerting a strong pressure and because of a lack of clearcut governmental responses to intolerance.

In the 2015 index that was recently released, Russia moved down 4 places to 152 th, China down to 176th, USA down to

\footnotetext{
${ }^{24} \mathrm{http}: / /$ www.theguardian.com/news/datablog/2014/dec/17/over-200journalists-in-prison-worldwide-for-third-consecutive-year

${ }^{25} \mathrm{https}$ ://www.cpj.org/reports/2014/12/journalists-in-prison-china-isworlds-worst-jailer.php

${ }^{26} \mathrm{https}: / /$ www.cpj.org/

${ }^{27} \mathrm{http}: / /$ rsf.org/index2014/en-index2014.php
}

49th, Germany down to 12th, UK down to 34th. France moved up to 38th, but the index was compiled before the Paris shooting.

Over the recent years, several journalists, political activists, and actors were sent to court or fired after they had expressed ideas, and views in a serious or comic way, which were found to offend either minorities or politicians.

Some examples of censorship are even more disturbing.

As reported by several newspapers and media in online's editions, ${ }^{28}$ the anti-Charlie Hebdo protest held in Niger on January 19th ended in 10 dead and 170 wounded.

Curiously, access to the original three $\mathrm{ABC}$ news links ${ }^{29}$ and to the Washington post pages ${ }^{30}$ listed on internet, that were reporting these events is now denied (at least from $\mathrm{Eu}-$ rope and the USA).

Is this a new example of press freedom of information or autocensorship?

What future to expect?

Freedom of the press should not be mistaken for permission to contort the truth (Fig. 1). ${ }^{31}$ Considering that the internet allows an extraordinary level of communication and diffusion of information, we as scientists know pretty well that the validity of the sources is critical, and that well established facts can sometimes be presented in conflicting ways.

Since the press is well known «to run the show $»^{32}$ it is vital that many different opinions can find their way into the media, and that journalism doesn't become the arm of governments, as too often seen in countries where freedom of expression is controlled.

Freedom of expression is not limited to verbal expression. It also applies to writing, singing, painting, drawing, dancing, all forms of art which are the target of intolerance.

\footnotetext{
${ }^{28}$ see for example : http://www.cnsnews.com/news/article/nigerdisperses-demo-after-10-die-charlie-hebdo-protests ; http://www. seattlepi.com/news/world/article/Niger-president-10-dead-after-antiCharlie-Hebdo-6022746.php ; http://www.boston.com/news/world/ africa/2015/01/18/niger-president-dead-after-anti-charlie-hebdo-protests/ iz8wmTf8E1X7i4H1zwAjpM/story.html

${ }^{29} \mathrm{http}: / / w w w . a b c n e w s 4 . c o m / s t o r y / 27878593 /$ niger-disperses-demoafter-10-die-in-charlie-hebdo-protests page not found ; http://www.abc-7. $\mathrm{com} /$ story/27878593/niger-disperses-demo-after-10-die-in-charliehebdo-protests page not found ; http://www.abc3340.com/story/ 27878593/niger-disperses-demo-after-10-die-in-charlie-hebdo-protests page not found

$30 \mathrm{http}: / / \mathrm{www}$.washingtonpost.com/world/africa/niger-president-10dead-after-anti-charlie-hebdo-protests/2015/01/18/d7cd565e-9f11-11e491 fc-7dff95a14458_story.html

${ }^{31}$ in english, the word freedom relates to the ability for acting in an independent way, without external control, whereas liberty, as it is in french, relates to a freedom that has been granted by an external source. For further reading on this topic see http://the-penultimate-word.com/ 2011/05/30/liberty-or-freedom-the-difference-is-amazing/ and http:// www.differencebetween.com/difference-between-freedom-and-vsliberty/

32 adapted from the french say « la presse fait la pluie et le beau temps »
} 


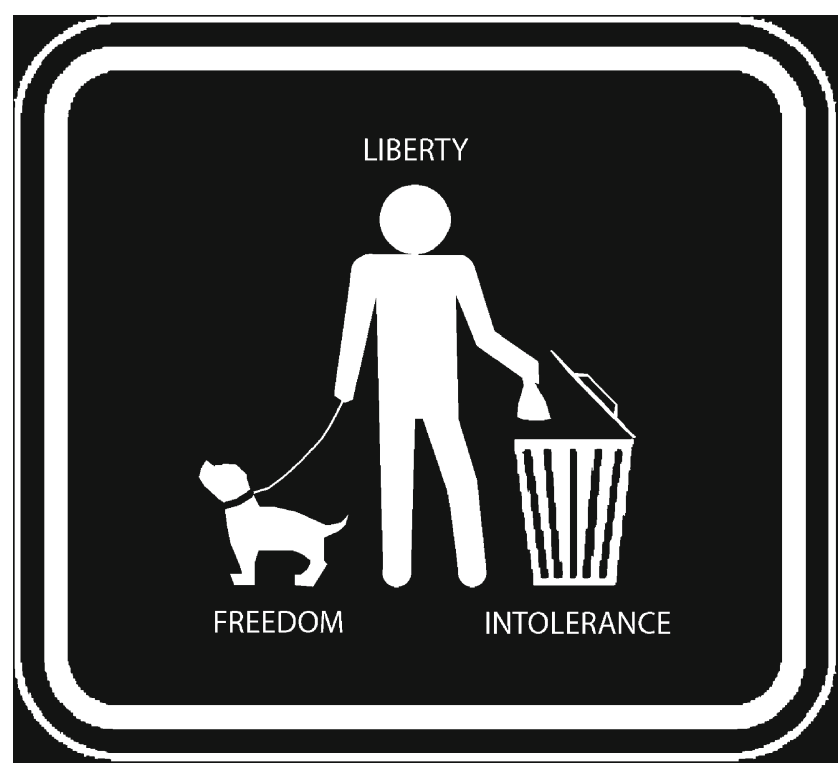

Fig. 1 Quote from Ludovic Gabaron, author of the cartoon: "Within the realm of Freedom some forms of expression are despicable, Liberty has to get rid of those."

The closing of facebook accounts ${ }^{33}$ showing a reproduction of the famous painting by Gustave Courbet called « l'origine du monde $»^{34}$ is a censorship showing another example of a modern form of intolerance .

\footnotetext{
$\overline{{ }^{33} \mathrm{http}: / / w w w .01}$ net.com/editorial/544800/facebook-assigne-en-justicepour-avoir-censure-un-nu-de-courbet/ ; http://www.boston.com/news/ world/africa/2015/01/18/niger-president-dead-after-anti-charlie-hebdoprotests/iz8wmTf8E1X7i4H1zwAjpM/story.html

34 « The origin of the world. » see http://www.musee-orsay.fr/en/ collections/works-in-focus/search/commentaire/commentaire id/theorigin-of-the-world-3122.html
}

A very sad example, was the bombing by catholic integrists of a movie theater in Paris for showing the « last temptation of the Christ ${ }^{35}$

Political intolerance and laxism, both have shown in the past to result in apartheid.

We should not tolerate crushing the lives of those who are rejected, censored, killed, because they do not fit in the mould of a « politically correct thinking ».

Freedom of expression was obtained after much fight. It is a very precious Value.

As a token of respect to those who gave their lives for our spiritual liberty we should not let it disintegrate and disappear with time.

We at JCCS and ICCNS, will always fight for freedom of expression and will promote new ideas as much as possible because we truly believe that "La liberté de la presse ne s'use que si l'on ne s'en sert pas." and fully agree with Rosa Luxemburg who said that " freedom is always and exclusively freedom for the one who thinks differently ${ }^{37}$

Acknowledgments We are grateful to $\mathrm{H}$. Yeger for critical reading of the manuscript and L. Gabaron for providing the cartoon contained in this article.

\footnotetext{
$\overline{{ }^{35} \text { Movie directed by Martin Scorsese in } 1988 .}$

${ }^{36}$ motto of the Canard Enchainé, a famous french satyrical journal, that could be translated as "Freedom (of the press ) only wears out when it is not used." Of course, it applies to all types of freedom.

${ }^{37}$ The Russian Revolution and Leninism or Marxism? (Ann Arbor Paperbacks) Paperback - November 15, 1961 by Rosa Luxemburg University of Michigan Press - ISBN: 9780472060573
} 